\title{
Fermentation of High Test Molasses ${ }^{1}$
}

\author{
Nivia F. de Murphy²
}

\begin{abstract}
The rate of fermentation of high test molasses (HTM) by yeast is slower than that of blackstrap molasses, probably because of the absence of certain yeast nutrients in HTM. Experiments were conducted with various sources of nutrients in an effort to increase the fermentation rate of HTM.

Highest fermentation rate and alcohol yield during fermentation of high test molasses were achieved when blackstrap molassses was used for the preparation of the yeast seed. Blackstrap molasses provided the nutrient balance necessary for more efficient fermentation. Similar use of rum distillery slops was also successful. Dehydrated yeast extract, although not economical, proved to be another source of nutrients.
\end{abstract}

\section{INTRODUCTION}

The economic importance of the Puerto Rico rum industry is a well established fact. It is the second more important source of economic revenue of the Island, with an annual gross income of more than 500 million dollars and over 270 million in government taxes. In 1980-1981. about 42 million gallons of blackstrap molasses (BM) were transformed into 38 million proof gallons of rum. Substantial production increase is expected in the near future.

The increasing operations of the rum producers, and consequently the increasing demand for molasses, has run parallel to a consistent decrease in its local supply. Forty-five million gallons of BM produced in 1970 gradually decreased to 13 million gallons in 1981; consequently, a considerable part of the supply has to be imported. A vigorous growing local rum industry should not depend on importing its principal raw material. The need for local production of a considerable amount of molasses is evident.

The rum industry of Puerto Rico has limited itself to the use of BM for fermentation since its price per available unit of sugar is lower than that of other sugarcane products. Puerto Rican sugar industry has declined continuously during the last decade. In some agricultural areas the sugarcane crop has been reduced drastically or it is on its way to extinction. This reduction is due to the drastic decrease in international sugar prices, making the enterprise unprofitable for Puerto Rican farmers and agricultural government agencies. An alternative, which may make feasible sugar cane production and ensure raw material for the local rum industry is the production of high test molasses (HTM) along with or

\footnotetext{
${ }^{\mathrm{I}}$ Submitted to Editorial Board December 20, 1982.

${ }^{2}$ Bacteriologist, Rum Pilot Plant, Agricultural Experiment Station, Mayagüez Campus, University of Puerto Rico, Río Piedras, P.R.
} 
instead of granulated sugar. High test molasses is defined as a clarified sugarcane syrup, partially inverted to avoid sugar crystallization, and evaporated to $85^{\circ}$ Brix. Its high content of fermentable sugars $(75-79 \%)$ and low ash content (2.2-2.0\%), would favor high test molasses for rum production.

A literature survey revealed that Cuba and the Philippines worked on the preparation of HTM from 1936 to 1956 (1, 3, 5, 6, 7, 8, 9, 10, 13). Africa also published work on this subject in 1968 (4). Details necessary for the successful applications of these methods are not available. Moreover, literature describes in detail fermentation procedures for BM but nothing has been published on alcoholic fermentation of HTM.

The Rum Pilot Plant, aware of the situation, initiated during the 1979 sugarcane harvest research work on the production and fermentation of HTM to offer this alternative to our sugarcane and rum industries. Studies were conducted at the Rum Pilot Plant and the Guánica Sugar Mill. As a result of these studies a manufacture procedure (14) that can be implemented parallel to normal sugar operations was recommended.

The nature of the substrate (source of sugars) bears a direct influence on its fermentation efficiency; therefore optimization of the fermentation process is specific for each substrate used. Usually molasses contains most of the yeast nutrients necessary for efficient growth and fermentation with the exception of nitrogen, phosphorus and certain growth factors. Nitrogen represents an important constituent of any growth and fermentation medium. A concentration of $1.5 \mathrm{~g} / \mathrm{l}$ of ammonium sulphate corrects the nitrogen deficiency in BM. Studies conducted in this plant (2) showed that the addition of $2 \mathrm{~g} / \mathrm{l}$ of ammonium sulphate as nitrogen source improves fermentation rates of HTM (fig. 1, 2).

Phosphorus is an important ionic factor in determining rate of fermentation; some growth factors, such as inositol, control the rate of fermentation. Although the deficiency in those nutrients is not critical in the case of BM, it does affect fermentation efficiency of HTM. Research was undertaken to establish an appropriate HTM nutrient fermentation environment. Studies on supplementation with necessary nutrients were conducted. This paper presents the results of these efforts.

\section{MATERIALS AND METHODS}

The general fermentation procedure consisted in diluting the molasses to a wort of optimum sugar concentration $(17-18 \mathrm{~g} / 100 \mathrm{ml})$ and the addition of desired nutrients, followed by inoculation with a vigorous growing yeast seed. For reduction of the bacterial contamination, the starting $\mathrm{pH}$ was adjusted to $4.7 \pm 0.1$ with concentrated sulfuric acid, 
and the wort was pasteurized at $170^{\circ} \mathrm{F}$ for $10 \mathrm{~min}$. Initial mashes were analyzed for total acidity and total sugars with methods described in the Official Analytical Methods of the Rum Pilot Plant (11). Fermentations were conducted in 20-liter glass fermenters each containing 16 liters total of fermenting mash, which included two liters of the yeast seed. The fermentation was allowed to proceed for 40 hours during which time



FIG. 1.-Fermentation curve of commercial high test molasses.

periodic ${ }^{\circ}$ Brix readings were recorded. The final fermented mashes were analyzed for ${ }^{\circ} \mathrm{Brix}, \mathrm{pH}$, total acidity, residual sugars and alcohol as described in the Official Analytical Methods of the Rum Pilot Plant (11). HTM manufactured at Guánica Sugar Mill and commercial BM obtained from a local distillery were used in this study. Typical composition of both high test and blackstrap molasses: 


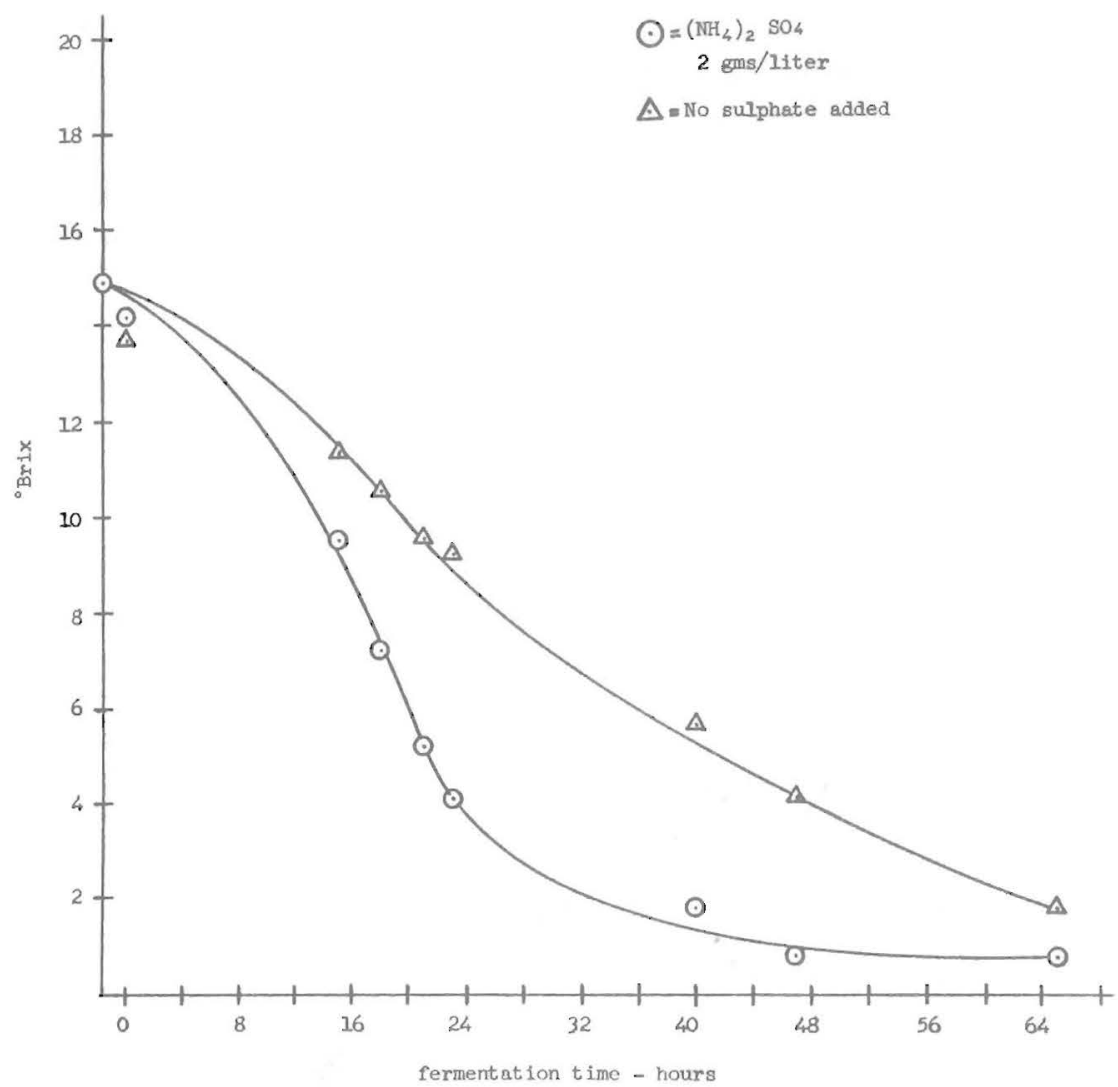

FIG. 2.-Fermentation curve of Rum Pilot Plant high test molasses.

Specific gravity, ${ }^{\circ}$ Brix

HTM

$80-86^{\circ}$

$5.0-5.7$

74-79

50-65

$12-26$

6.0-7.5

$2.2-3.0$

0.1

0.22
$\mathrm{BM}$

$86^{\circ}$

5.6

57

20

37

29.0

9.6

0.5

0.55

Sulfur (\%)

The initial optimum sugar concentration of $17-18 \%$ was attained by diluting HTM to approximately $17^{\circ}$ Brix and BM to $24^{\circ}$ Brix with tap water. The inoculum was prepared by successive transfers of Saccharomyces cerevisiae yeast strain PPR-80 to larger amounts of the diluted 
raw material. Stock culture was maintained on synthetic media agar slants as described in Official Bacteriological Methods and Procedures of the Rum Pilot Plant (12). From there, transfers were made to Erlenmeyer flasks containing $50 \mathrm{ml}$ liquid synthetic medium and allowed to grow aerobically overnight with mechanical agitation. The flask contents were then aseptically transferred to $250 \mathrm{ml}$ molasses medium and mechanically agitated again for the same period of time. The required amount of vigorous active seed ( $12.5 \%$ of total fermentation volume) was built up in this manner.

Two groups of experiments were conducted:

\section{FIRST GROUP}

HTM medium was supplemented with additional nutrients as follows: ammonium sulphate as source of nitrogen, potassium phosphate as source of phosphorus, and dehydrated yeast extract which provided yeast growth factors.

Yeast inoculum was prepared in a HTM medium of the same composition as the subsequent HTM fermentation mash. The nutrients were added in the following combinations, triplicate samples per variable:

$\begin{array}{lccccccc}\quad \text { Fermenters } & 1-3 & 4-6 & 7-9 & 10-12 & 13-15 & 16-18 & 19-21 \\ \left(\mathrm{NH}_{4}\right)_{2} \mathrm{SO}_{4}(\mathrm{~g} / \mathrm{l}) & 2 & 2 & 2 & 2 & 2 & 2 & 2 \\ \mathrm{KH}_{2} \mathrm{PO}_{4}(\mathrm{~g} / \mathrm{l}) & 0 & 0.5 & 0 & 0 & 0 & 0.5 & 0.5 \\ \text { Yeast extract }(\mathrm{g} / \mathrm{l}) & 0 & 0 & 0.5 & 1 & 2 & 1 & 2\end{array}$

\section{SECOND GROUP}

Additional nutrients were provided by complex sources such as BM and rum distillery slops, used mainly in the preparation of the inoculum. A typical composition of rum slops;

\section{Component}

$\%$

Total solids

8.15

Organic solids

6.00

Inorganic solids

2.15

Carbon (C)

1.85

Crude protein

0.95

Potassium $\left(\mathrm{K}_{2} \mathrm{O}\right)$

.78

Sulfur $\left(\mathrm{SO}_{4}\right)$

.64

Calcium $(\mathrm{CaO})$

.36

Chlorine $(\mathrm{NaCl})$

Nitrogen (N)

Magnesium ( $\mathrm{MgO}$ )

Phosphorus $\left(\mathrm{P}_{2} \mathrm{O}_{5}\right)$ 
The inoculation media consisted of either HTM, HTM + slops, HTM + BM, or BM, all diluted to the desired ${ }^{\circ}$ Brix with tap water. Fermentation media consisted of HTM diluted to the required ${ }^{\circ}$ Brix with either tap water or a mixture of tap water and rum slops (back slopping). Additional nitrogen was added to each fermenter in the form of $2 \mathrm{~g} / \mathrm{l}$ of ammonium sulphate.

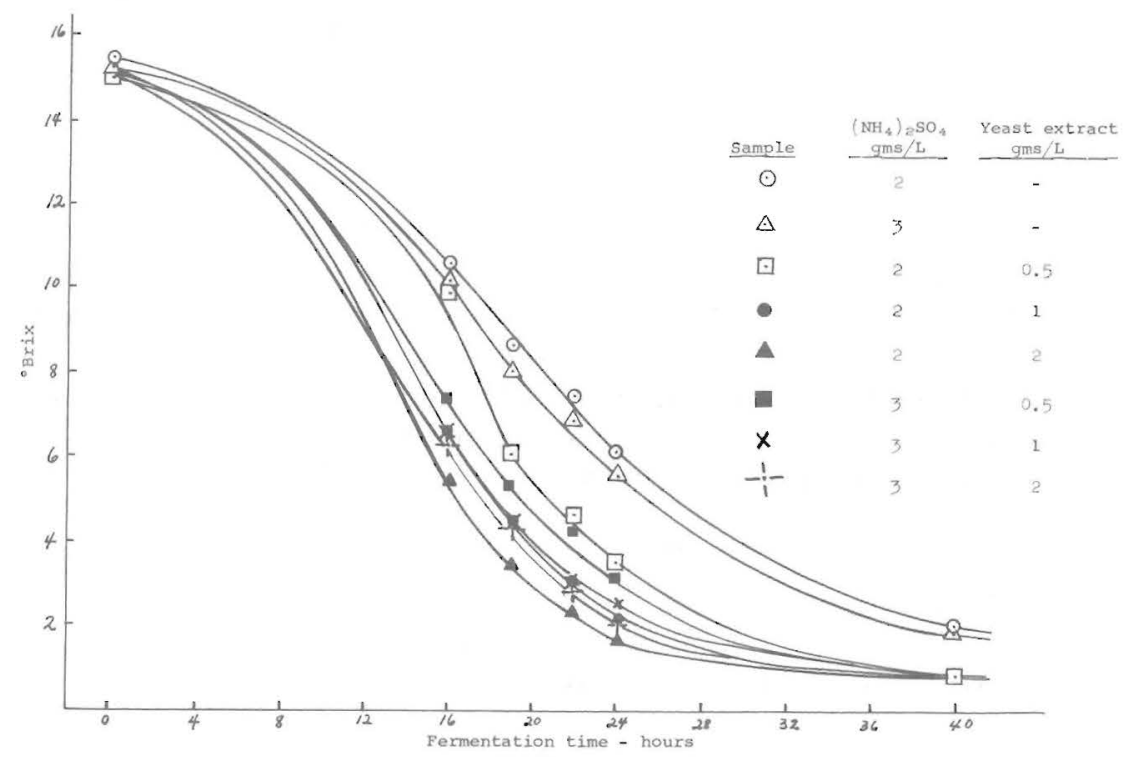

FIG. 3.-Laboratory fermentation of experimental high test molasses.

The following summary describes seed medium and fermentation medium:

Fermenters $\quad 1-3 \quad 4-6 \quad 7-9 \quad 10-12 \quad 13-15 \quad 16-18 \quad 19-21 \quad 22-24$

Seed Media

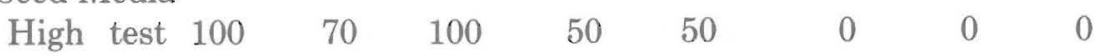

molasses

$\%$

$\begin{array}{lllllllll}\text { Blackstrap } & 0 & 0 & 0 & 50 & 50 & 100 & 100 & 100\end{array}$

molasses

$\%$

Slops \%

Fermen-

tation

$0 \quad 30$

0

$0 \quad 0$

0

$0 \quad 0$

media 

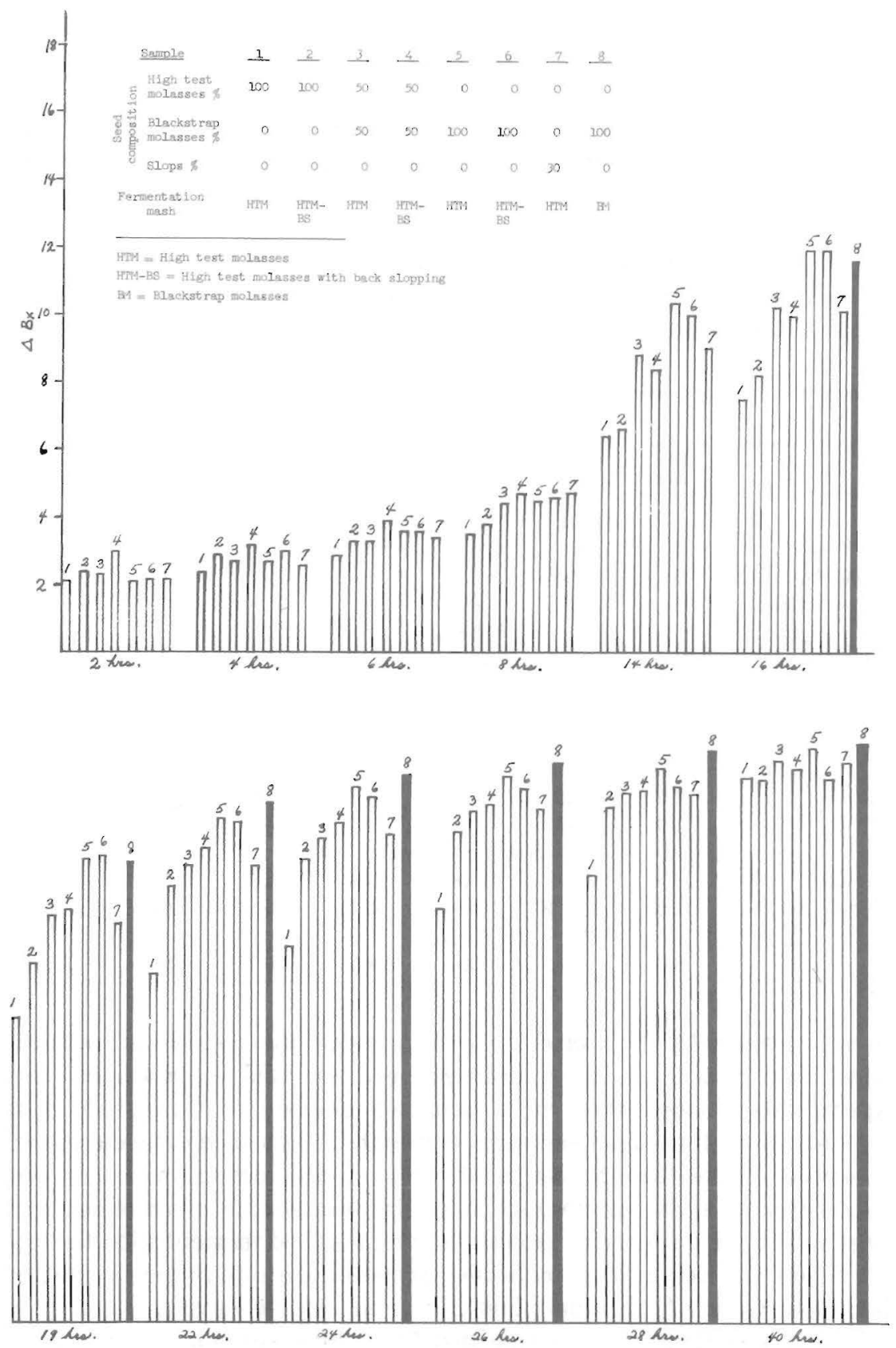

FIG. 4.-Comparative laboratory fermentation tests. 


\section{RESULTS}

The time course and analytical results are presented in tables 1 and 2 and figures 3 and 4.

From data in figure 3 it is evident as preliminarily determined that additional nutrients are necessary in order to accomplish a more efficient HTM fermentation; their omission decreased the overall rate and yield of the fermentation.

It is known that fermentation rate on an optimum fermentation environment is proportional to the amount of yeast present. During the course of the fermentation, part of the initial inoculum is being replaced

TABLE 1.-Rate of fermentation of High Test Molasses by yeast under various nutrient conditions

\begin{tabular}{|c|c|c|c|c|c|c|c|}
\hline Sample & $\begin{array}{l}240- \\
242 \\
\end{array}$ & $\begin{array}{l}243- \\
245\end{array}$ & $\begin{array}{l}246- \\
248 \\
\end{array}$ & $\begin{array}{c}249- \\
251 \\
\end{array}$ & $\begin{array}{c}252- \\
254 \\
\end{array}$ & $\begin{array}{l}255- \\
257 \\
\end{array}$ & $\begin{array}{l}258- \\
260\end{array}$ \\
\hline \multicolumn{8}{|c|}{ Nutrient g/l } \\
\hline$\left(\mathrm{NH}_{4}\right)_{2} \mathrm{SO}_{4}$ & 2 & 2 & 2 & 2 & 2 & 2 & 2 \\
\hline $\mathrm{KH}_{2} \mathrm{PO}_{4}$ & 0 & 0.5 & 0 & 0 & 0 & 0.5 & 0.5 \\
\hline Yeast extract & 0 & 0 & $\begin{array}{c}0.5 \\
{ }^{\circ} \text { Brix }\end{array}$ & 1 & 2 & 1 & 2 \\
\hline 0 hrs. & 17.4 & 17.4 & 17.4 & 17.4 & 17.4 & 17.4 & 17.4 \\
\hline 0 & 15.0 & 14.8 & 14.9 & 14.9 & 14.9 & 15.0 & 15.1 \\
\hline 16 & 6.2 & 5.6 & 4.9 & 4.6 & 3.7 & 4.2 & 3.8 \\
\hline 19 & 4.4 & 4.3 & 3.6 & 3.2 & 2.4 & 2.9 & 2.5 \\
\hline 22 & 3.3 & 3.0 & 2.4 & 2.5 & 1.6 & 1.8 & 1.5 \\
\hline 24 & 2.5 & 2.2 & 1.8 & 1.7 & 1.0 & 1.1 & 1.2 \\
\hline 40 & 1.0 & 0.8 & 0.8 & 0.7 & 0.7 & 0.6 & 0.7 \\
\hline \multicolumn{8}{|c|}{ Sugar g/100 ml } \\
\hline Initial & 17.8 & 17.8 & 17.8 & 17.8 & 17.8 & 17.8 & 17.8 \\
\hline \multirow[t]{2}{*}{ Final } & 1.05 & 0.72 & $\begin{array}{c}0.84 \\
\text { Alcohol }\end{array}$ & 0.71 & 0.52 & 0.63 & 0.52 \\
\hline & 8.8 & 8.8 & 9.0 & 9.0 & 9.1 & 9.0 & 9.2 \\
\hline
\end{tabular}

by new yeast cells. The medium must provide the nutritional requirements that yeasts as living entities need for this replacement. Our experiments showed that for a balanced environment in HTM, the concentration of nitrogen and certain growth factors need to be increased. Otherwise, fermentation rate is affected. It was determined that two grams/liter of each, ammonium sulphate as a source of nitrogen, and yeast extract as a source of growth factors, reduced fermentation time to $25-28$ hours. Yeast extract increased fermentation rate proportionally to the amount used. Additional phosphorus was not necessary.

Table 2 and figure 4 show that distillery slops were also successful in providing necessary nutrients. Whether used in the preparation of yeast seed or as diluent for the preparation of fermentation mash (back- 
TABLE 2.- Rate of fermentation of HTM by yeasts under various nutrient conditions

\begin{tabular}{|c|c|c|c|c|c|c|c|c|}
\hline Sample & $1-3$ & $4-6$ & $7-9$ & $10-12$ & $13-15$ & $16-18$ & $19-21$ & $22-24$ \\
\hline \multicolumn{9}{|c|}{ Seed media composition } \\
\hline $\begin{array}{l}\text { High Test mo- } \\
\text { lasses \% }\end{array}$ & 100 & 70 & 100 & 50 & 50 & 0 & 0 & 0 \\
\hline $\begin{array}{l}\text { Blackstrap mo- } \\
\text { lasses } \%\end{array}$ & 0 & 0 & 0 & 50 & 50 & 100 & 100 & 100 \\
\hline Slops \% & 0 & 30 & 0 & 0 & 0 & 0 & 0 & 0 \\
\hline $\begin{array}{l}\text { Fermentation } \\
\text { media }\end{array}$ & $\mathrm{HTM}^{1}$ & HTM & $\mathrm{HTM}_{\mathrm{T}} \mathrm{BS}^{2}$ & HTM & HTM-BS & HTM & HTM-BS & $\mathrm{BM}^{3}$ \\
\hline \multicolumn{9}{|c|}{${ }^{\circ}$ Brix } \\
\hline 0 hrs. & 1.7 & 1.8 & 2.2 & 1.9 & 2.5 & 1.8 & 1.9 & 1.2 \\
\hline 2 & 2.1 & 2.2 & 2.4 & 2.3 & 3.0 & 2.1 & 2.2 & - \\
\hline 4 & 2.4 & 2.6 & 2.9 & 2.7 & 3.2 & 2.7 & 3.0 & - \\
\hline 6 & 2.9 & 3.4 & 3.3 & 3.3 & 3.9 & 3.6 & 3.6 & - \\
\hline 8 & 3.5 & 4.7 & 3.8 & 4.4 & 4.7 & 4.5 & 4.6 & - \\
\hline 14 & 6.4 & 9.0 & 6.6 & 8.8 & 8.3 & 10.3 & 10.0 & - \\
\hline 16 & 7.5 & 10.1 & 8.2 & 10.2 & 9.9 & 11.9 & 11.9 & 11.5 \\
\hline 19 & 9.0 & 11.8 & 10.6 & 12.0 & 12.2 & 13.7 & 13.8 & 13.6 \\
\hline 22 & 10.3 & 13.5 & 12.9 & 13.5 & 14.0 & 14.9 & 14.8 & 15.3 \\
\hline 24 & 11.1 & 14.4 & 13.7 & 14.3 & 14.8 & 15.8 & 15.5 & 16.1 \\
\hline 26 & 12.2 & 15.1 & 14.5 & 15.1 & 15.3 & 16.1 & 15.7 & - \\
\hline 28 & 13.2 & 15.6 & 15.2 & 15.6 & 15.7 & 16.3 & 15.8 & 16.8 \\
\hline 40 & 16.0 & 16.5 & 15.9 & $\begin{array}{l}16.5 \\
{ }^{\circ} \text { Brix }\end{array}$ & 15.8 & 16.8 & 16.0 & 17.0 \\
\hline Initial & 17.7 & 17.9 & 20.6 & 17.8 & 20.8 & 18.6 & 21.4 & 24.3 \\
\hline After Inoc. & 16.0 & 16.1 & 18.4 & 15.9 & 18.3 & 16.8 & 19.5 & 23.1 \\
\hline Final & 1.7 & 1.4 & 4.7 & $\begin{array}{l}1.3 \\
p H\end{array}$ & 5.0 & 1.8 & 5.4 & 7.3 \\
\hline Initial & 4.96 & 5.00 & 5.18 & 4.80 & 5.03 & 5.01 & 5.24 & 4.82 \\
\hline Final & 3.90 & 4.02 & 4.70 & 3.93 & 4.58 & 4.28 & 4.60 & 4.74 \\
\hline
\end{tabular}


TABLE 2.-Rate of fermentation of HTM by yeasts under various nutrient conditions

\begin{tabular}{|c|c|c|c|c|c|c|c|c|}
\hline Sample & $1-3$ & $4-6$ & $7-9$ & $10-12$ & $13-15$ & $16-18$ & $19-21$ & $22-24$ \\
\hline \multicolumn{9}{|c|}{ Seed media composition } \\
\hline $\begin{array}{l}\text { High Test mo- } \\
\text { lasses } \%\end{array}$ & 100 & 70 & 100 & 50 & 50 & 0 & 0 & $\theta$ \\
\hline $\begin{array}{l}\text { Blackstrap mo- } \\
\text { lasses } \%\end{array}$ & 0 & 0 & 0 & 50 & 50 & 100 & 100 & 100 \\
\hline Slops \% & 0 & 30 & 0 & 0 & 0 & 0 & 0 & 0 \\
\hline $\begin{array}{l}\text { Fermentation } \\
\text { media }\end{array}$ & HTM $^{1}$ & HTM & $\mathrm{HTM} \mathrm{BS}^{2}$ & HTM & HTM-BS & HTM & HTM-BS & $\mathrm{BM}^{3}$ \\
\hline \multicolumn{9}{|c|}{ Acidity g/l } \\
\hline Initial & 1.19 & 1.33 & 2.32 & 1.31 & 2.40 & 1.48 & 2.59 & 4.15 \\
\hline Final & 3.55 & 3.48 & 4.59 & 3.49 & 4.36 & 3.81 & 4.74 & 6.21 \\
\hline \multicolumn{9}{|c|}{ Sugar g/100 ml } \\
\hline Initial & 17.0 & 16.8 & 16.8 & 16.8 & 16.6 & 17.2 & 17.2 & 18.6 \\
\hline Final & 1.27 & 0.66 & 0.80 & 0.61 & 0.79 & 0.58 & 0.83 & 1.25 \\
\hline \% Alcohol & 8.58 & 8.96 & 8.76 & 8.84 & 8.82 & 9.25 & 9.03 & 9.69 \\
\hline
\end{tabular}

${ }^{1} \mathrm{HTM}=$ High test molasses.

${ }^{2}$ HTM-BS $=$ High test molasses with $30 \%$ back slopping.

${ }^{3} \mathrm{BM}=$ Blackstrap molasses. 
slopping), rum slops, and economically attractive alternative, accelerated fermentation of HTM. Better results were obtained supplementing the nutrients in the seed media rather than back-slopping the fermentation mash.

BM was another good source of additional nutrients. As its analysis shows, it is significantly higher in nitrogen and in soluble non sugar contents than HTM. Although it is known that high concentrations of some individual components of molasses may be detrimental, the overall composition of $\mathrm{BM}$ provided a better environment for the preparation of yeast seed (table 2; fig. 4). The use of 50 and $100 \%$ concentrations in seed medium contributed to a more efficient fermentation of HTM; the improvement was proportional to the amount of BM used. When BM. was used as seed media, back-slopping fermentation mash was not necessary.

It was demonstrated that, under the conditions of this study, BM supplemented with ammonium sulphate proved to be the best nutrient source for an efficient fermentation of HTM.

\section{RESUMEN}

Experimentos hechos para optimar la fermentación alcohólica de las mieles ricas demostraron deficiencias en nitrógeno y otros factores de crecimiento de las levaduras que afectan la eficiencia fermentativa de estas mieles.

Estudios para corregir estas deficiencias indican que la miel final de caña contiene la mayoria de estos nutrimentos, inclusive vitaminas y demás factores de crecimiento, excepto el nitrógeno.

La rapidez máxima de fermentación y el máximo contenido alcohólico se consiguieron preparando la semilla de levadura en miel final y añadiendo sulfato amónico como fuente de nitrógeno.

El residuo de la destilación de ron también fue una buena fuente de nutrimentos. El extracto de levaduras provee los nutrimentos necesarios, pero es un ingrediente relativamente costoso.

\section{LITERATURE CITED}

1. Ancheta, T. R., 1956. A study of the possibilities of high test molasses production, Proc. Philippines Sugar Tech. Conv., 243-53.

2. Annual Progress Report, 1979. Project H-279 "Factors affecting fermentation efficiency of molasses by yeast and effects on quality of rums, Rum Pilot Plant, Agric. Exp. Stn., Mayagüez Campus, Río Piedras, P.R.

3. Argüelles, B. R., 1939. Aplicación de los métodos conductométricos en el control de la inversión, Asoc. Téc. Azucareros Cuba, Memorias 13: 195-98.

4. De Broglio, A., Hulett, J. R., April 1968. The manufacture of high test molasses at Hulett's Mount Edgecombe Mill, Proc. South Afric. Sugar Technol. Assoc., pp. 5556. 


\section{JOURNAL OF AGRICULTURE OF UNIVERSITY OF PUERTO RICO}

5. Diago, R. A. and Mascaró, M. A., 1936. Estudio sobre producción de meladuras invertidas concentradas (Mieles invertidas), Proc. Cuban Sugar Tech. Assoc. 10: 101-08.

6. Forn, C. A., 1940. Inutilidad de la esterilización en la fabricación de mieles invertidas con invertasa, Asoc. Téc. Azucareros Cuba 14: 303-04.

7. Fowler, A. P., 1939. La producción de levadura en los ingenios para hacer mieles invertidas, Asoc. Téc. Azucareros Cuba, Memorias 13: 227-30.

8. González-Maiz, Julio C., 1939. Fabricación de mieles ricas con levadura invertasa, Asoc. Téc. Azucareros Cuba, Memorias 13: 181-

9. Lima-Romero, J. J., 1940. Las enzimas, la variación del pH y los aminoácidos en las mieles invertidas, Asoc. Azucareros Cuba 14: 305-08.

10. López-Ferrer, F. A., 1940. Control químico en la fabricación de mieles invertidas, Asoc. Téc. Azucareros Cuba 14: 295-301.

11. Official Analytical Methods of the Rum Pilot Plant, 1969. Agric. Exp. Stn., Mayagüez Campus, UPR, Río Piedras, P.R.

12. Official Bacteriological Methods of the Rum Pilot Plant 1969. Agric. Exp. Stn., Mayagüez Campus, UPR, Río Piedras, P.R.

13. Osuna, J. R., 1940. Enfriamiento continuo de meladuras invertidas, Asoc. Téc. Azucareros Cuba, Memorias 14: 289-93.

14. Rosado, E., 1982. Manufacture of high test molasses, Progress Report No. 23-83, Rum Pilot Plant, Agric. Exp. Stn. Univ. P.R., Rio Piedras, P.R. 